\title{
GEOGRAPHIC CORRELATES OF LOWEST AVAILABLE AIRFARES \\ ON AUSTRALIAN AIR ROUTES
}

Kurt Fuellhart ${ }^{1}$

Shippensburg University, Pennsylvania, USA

Ben Derudder ${ }^{2}$,

Department of Geography, Ghent University, Belgium

Kevin O'Connor ${ }^{3}$,

University of Melbourne, Australia

Weiyang Zhang ${ }^{4}$

Department of Geography, Ghent University, Belgium

\section{ABSTRACT}

Deregulation of the airline industry in Australia has produced lower airfares. However this perspective rarely incorporates spatial insights and usually utilizes archival data. The purpose of this paper is to conduct a first-stage confirmatory analysis of up-to-date airfares charged on 24 major routes within Australia using Skyscanner, a web-based and consumer-oriented tool to access

\footnotetext{
${ }^{1}$ Corresponding author. Kurt Fuellhart is Professor of Geography at Shippensburg University in Pennsylvania, U.S.A. His research focuses on regional economic analysis and air transport, particularly regarding multiple airport areas, the Asia/Pacific region and the United States. E-mail: kgfuel@ship.edu.
}

2 Ben Derudder is Professor of Urban Geography at Ghent University's (Belgium) Department of Geography, and an Associate Director of the Globalization and World Cities (GaWC) research network. His research focuses on the conceptualization and empirical analysis of transnational urban networks in general, and the role of air transport networks in the formation of these urban networks in particular.

${ }^{3}$ Kevin O'Connor is Professorial Fellow at the University of Melbourne. His research explores the links between the economy and the growth and internal structure of cities with a current focus upon airports and city development in the Asia Pacific region. He is Associate Editor-Asia Pacific for the Journal of Transport Geography.

${ }^{4}$ Weiyang Zhang is a PhD student at Ghent University's Department of Geography. He holds a Master's degree in Human Geography from the University of the Chinese Academy of Sciences (Nanjing). His PhD research focuses on urban networks and polycentricity in Chinese mega-city regions. 
airfares. This tool displays fares during an on-line booking process prior to purchase, just as consumers would experience it. We apply Skyscanner to extract one set of current fares -- lowest fare data -- on the routes and then use linear modelling to establish variables that can be utilized to predict these lowest fare prices. While far from a full accounting of the cost of Australian air services, this test of Skyscanner as a data source, along with the successful confirmatory linear analysis, shows that the underlying configuration of the nation's urban population, distance, direct connections, and characteristics of links and networks of low cost carriers are powerful influences upon prices charged. We suggest that Skyscanner and similar data sources may provide researchers with alternative low cost data that may shed insight into many air transport pricing questions.

Keywords: Australia, airfares, Skyscanner, confirmatory linear analysis, urban networks 


\section{INTRODUCTION}

The purpose of this paper is to examine the spatial variation in the lowest airfare cost of inter-city travel within Australia using a non-traditional data set. Given the relatively large average distances between Australian cities, air transport is by far the most important, and in some cases even the only viable way for convenient inter-connections between places. As a consequence, air passenger transport is the key to Australia's day-to-day territorial integration, and understanding its configuration is therefore critical to its role in that nation's broader social context. To date, research on the geography of Australia's domestic air services has focused on the supply of connections (Fuellhart and O'Connor, 2012) which reflected the outcomes of corporate restructuring (Weller, 2009) and the impact of new low cost carriers (Forsyth, 2003).

In this research we change the focus of the analysis to the perspective of the consumer and explore the lowest available fare for a range inter-city connections using a web-based tool - Skyscanner -that is also accessible by prospective passengers. We show how location within the country is important to the air fares charged so that the activity of the airline industry is linked in no small way to the geography of social equity with the country. In doing so, we suggest that Skyscanner and similar web sites may have considerable utility to air transport analysts. This extension of the research provides a more nuanced understanding of the relative friction of distance of traveling between city pairs and acknowledges the importance of the mind-set of a consumer looking for a ticket at the lower end of available price options. While the lowest fare is not the only fare consumers shop for, the analysis of lowest cost tickets across routes provides a starting point for the assessment of Skyscanner as a research tool. In doing so the paper both explores the spatial equity of the airline deregulation while providing a supply-side price analysis of Australian air travel.

It is clear that the fare charged for airline connections is the result of a complex interplay between cities' locations, distance between one another, their size and industrial structure, and the wider market context in which airlines operate. That complex interplay has been explored in analyses of major geographical factors that influence airfare pricing in different domestic markets. The relative importance, and the spatial consequences, of these factors tend to play out differently: pricing in a large and liberalized market such as the United States (Reynolds-Feighan, 2001) obviously differs from that in a geographically smaller and regulated market such as Japan (Yamachuci, 2000, Zhang et al. 2008), while at a continental scale the experience of pricing in Canada (Mentzer, 2000) and the US differs from that in the European Union (Alderighi et al., 2004, Goetz and Graham, 2004). This is partly because of the impact and presence of alternative travel modes and the geographical outline of the respective urban systems. 
To take these analyses a stage further requires finer scale city-specific and time-specific data. The lack of data outside the US means much research on pricing has relied upon archival data provided in the Airfare Consumer Report, published quarterly by the U.S. Department of Transportation's (USDOT) Office of Aviation Analysis (Brueckner et al., 2013, Fuellhart et al., 2013, Neal, 2014) as well as other databases. These data typically provide information on average fares actually (and already) paid across fare classes over different periods of time. However, the expansion of online booking systems has opened up new possibilities for research on this aspect as shown in Zhang et al. (2013) and Zook and Brunn (2005, 2006). We test one such possibility to present an analysis of the geographies of lowest-market airfares in the Australian context. Put differently, we explore the air travel price-point opportunities that exist for market-wise airline shoppers by analysing the lowest fares actually on offer and available at the time of sale by using a real-time fare quoting system available to all consumers with a web connection. The goal is to conduct a confirmatory examination of the components of Australian airfares using this one specific and constrained group of fares both to comment on the makeup of the fares themselves and the potential use of Skyscanner for more complex analyses.

The remainder of this paper is organized as follows: First we provide a brief literature review on trends in the airline industry in general and in Australia in particular, focusing on the potential drivers of pricing in a liberalized market such as Australia. Second, we describe the empirical framework and methodology. Third, we examine the results of the confirmatory analysis both through descriptive assessment and statistical modelling. Finally, we wrap up the paper with a discussion of the implications of the study and suggest some issues for future research.

\section{LIBERALIZATION IN THE AIRLINE INDUSTRY AND THE GEOGRAPHY OF AIRFARES}

The airline industry is one of the economic sectors where the effects of a neoliberal praxis have been substantial (Bowen, 2002, Weller, 2009). In general, government regulation and control has increasingly been replaced by an ethos of liberalization, which involves both deregulation (i.e. the relaxation or removal or regulations on passenger fares, air freight rates, market entry and exit, choice of routes and aircraft, level of service, and forms of competition and collaboration) and privatization (i.e. the transfer in whole or in part of airlines from the public sector to the private sector). Although deregulation and privatization in the airline industry are best understood as ongoing bundles of processes that develop unevenly in time, space, and form, it is clear that air transport is now increasingly subject to free-market forces, achieved through the removal of most regulatory controls over pricing, while at the same time - at least theoretically - permitting carriers 
to enter and leave certain markets at will. From a supply standpoint, air transport may be among the most footloose industries in the world.

Liberalisation has been expressed geographically in two major dimensions. The first is that the route structures that make up airlines' networks in deregulated markets have come to be a combination of (1) more direct and nonstop services between important cities or wherever the traffic volumes justify and (2) hub-and-spoke structures for interconnecting other city-pairs (O'Kelly, 1998, Derudder and Witlox, 2009). These dimensions intersect when the "important cities" are also the hubs, as services to the hub can provide economies of scale and scope in aircraft operations. The geographic selectivity in favour of large cities, those centrally located, or international gateways has re-shaped the distribution of air services away from the patterns established under regulation. Goetz (2002:7) found significant impacts of this change on airfares, identifying "pockets of (fare) pain" in U.S. locations outside the new focal points. Lee and Luengo-Prado (2005) illustrate that effect by showing that the fare outcomes reflect differences between cities in their mix of passengers (business versus leisure).

The second dimension has been the entry into the market of low-cost carriers. Although specifying carrier typologies is an increasingly difficult task, the air transport literature generally distinguishes between two types of carriers, i.e. full-service carriers (FSCS) and low-cost carriers (LCCS). FSCs run a complex business model bundling a series of services, using sophisticated yield management techniques to utilize their fleet of multiple aircraft types, along with in-flight entertainment, VIP waiting lounges, complex frequent flyer benefits, and other 'frill' services (Hazledine, 2010). The USDOT (2005) definition of LCCs uses a business model approach and focuses upon dimensions such as (i) the presence of a single passenger cabin class, (ii) the 'no frills' service, (iii) standardized aircraft utilization, and other characteristics. LCCs tend to more often deploy point-to-point network structures and offer more direct flights (Gillen and Morrison, 2005). The fundamental impact of the LCC has been upon price, so that the geography of their services is critical to the geography of the airfares at both specific airports and within multi-airport regions.

These two dimensions can intersect. Some LCCs' networks are now so extensive that they too operate hubs. In the US context, for instance, it is estimated that nearly $20 \%$ of LCC Southwest Airlines' passengers now arrive at their destination by transferring onto another flight at one of its hubs (Taneja, 2004). In addition, FSCs have launched their own low-cost subsidiaries in response to the low-cost competition (e.g. Jetstar by Qantas) (Graham and Vowles, 2006). In this context the provision of services to cities, and the fares charged to reach them, is shaped not only by the basic network configuration but also by the part that LCC operations play in that network. These two 
dimensions provide a framework to analyse geography of the cost of air travel within Australia, utilising a new data source on airfares.

\section{THE AUSTRALIAN CONTEXT: POLICY, ROUTE STRUCTURE, CARRIERS, AND OTHER FACTORS}

\subsection{Deregulation}

Prior to 1990 Australia had a regulated air transport industry, called the "Two Airline Policy", a heritage discussed in detail by Weller (2007). In 1990, that approach was removed, and a deregulated era began (Forsyth, 1991). Details of the change are summarised in a National Aviation Policy Paper of the Australian government (Australian Government, 2009). Looking back to the decisions of 1990, that report observed (p.7):

"Australia's domestic interstate aviation market has been deregulated for nearly twenty years. Competition and the ability of the industry to respond to market demand has seen airlines offer lower prices, more flights and a wider variety of services than was the case before deregulation. The result has been increasing numbers of Australians travelling by air to do business, to educate themselves or simply to enjoy themselves. Domestic air travel has more than trebled over the past twenty years, with over 50 million passenger movements in 2008-09 through more than 180 domestic airports".

And, more specifically with respect to fares ( $p 55)$ :

"Within five years of the abolition of the two airlines policy air fares had fallen by 22 per cent. Consumer benefits have continued to flow, with the best discount fares in 2009 a further 40 per cent cheaper, in real terms, than equivalent fares in 1995".

Though this observation is a commonly expressed one, the data in Figure 1 shows that outcome has been very dependent upon the type of fare. Large falls have been recorded in the "best discount" fare, but less change has been felt elsewhere. De Roos et al. (2010) show that outcome reflects head-to-head competition between Virgin Australia and Qantas, as well as the presence of a LCC. Falls in domestic fares have slowed, and indeed some of the fall has been reversed. For residents in cities that have limited or no service from LCCs, this latter outcome might be particularly relevant. 


\section{(13 month Moving Average Value)}

160.0

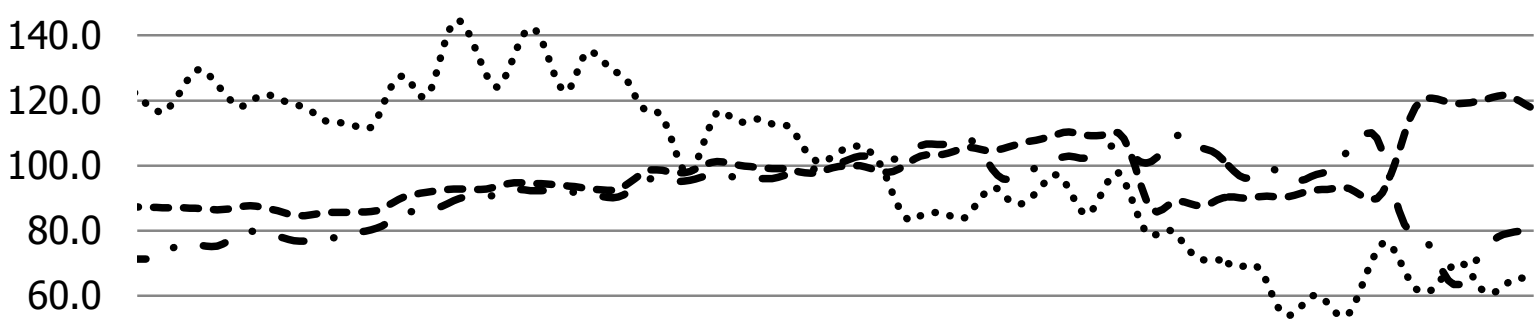

40.0

20.0

0.0

$$
\begin{aligned}
& \text { ๙ }
\end{aligned}
$$

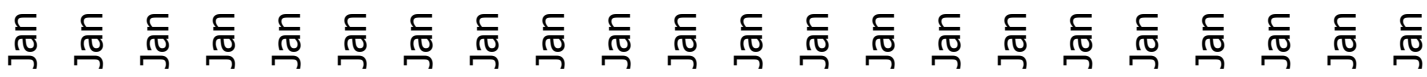

$$
\begin{aligned}
& \text { - - Business - - - Full Economy ..... Best Discount }
\end{aligned}
$$

Source: BITRE Australian Domestic Air Fare Indexes

The key issue for the current research is the lowest price charged on actual routes. Insight on that outcome is provided by the data displayed in Figure 2, where we examine 24 of the most important nodes in Australian air transport and display the average of the lowest fare available at each city (details of its precise calculation are provided below, and see Figure 3 for a map of the cities). This data shows there is a 3.5 times difference between the cities with the three lowest fares (Melbourne, Sydney and Brisbane) and the three with the most expensive (Karratha, Port Hedland and Ayers Rock). Just six years after the deregulation of the Australian airline industry, Quiggin (1997:54) observed that "the distributional effects of deregulation are unclear, but are probably favourable on balance". Some twenty years on, and after the introduction of LCCS, the data in Figure 2 suggests the distributional and geographic effects may be more severe than was apparent in 1997. 
Figure 2- Average Cost Lowest Price Fare Available

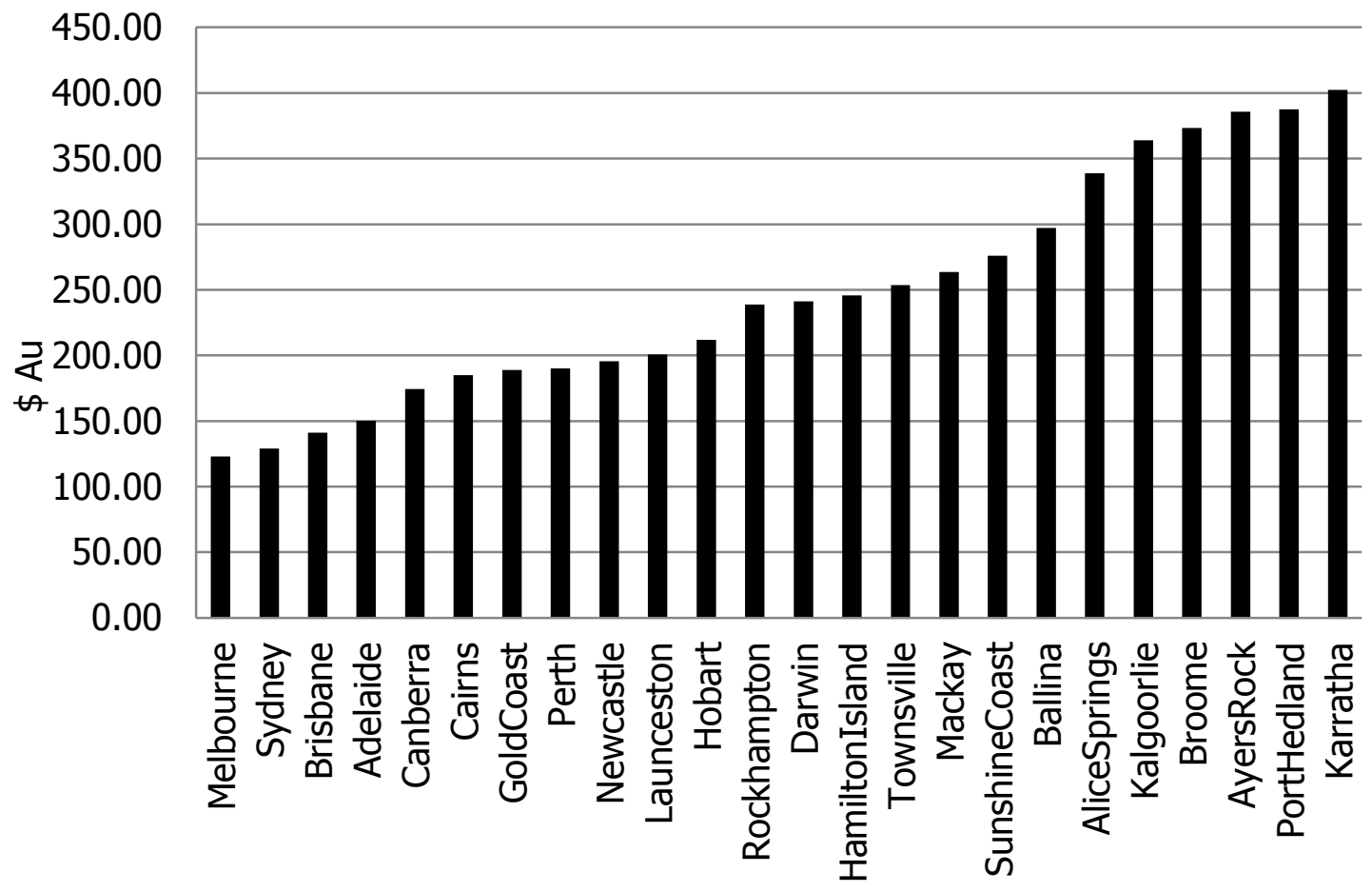

Source: Skycanner 2013

Figure 3 - 24 Major Air Traffic Nodes in Australia

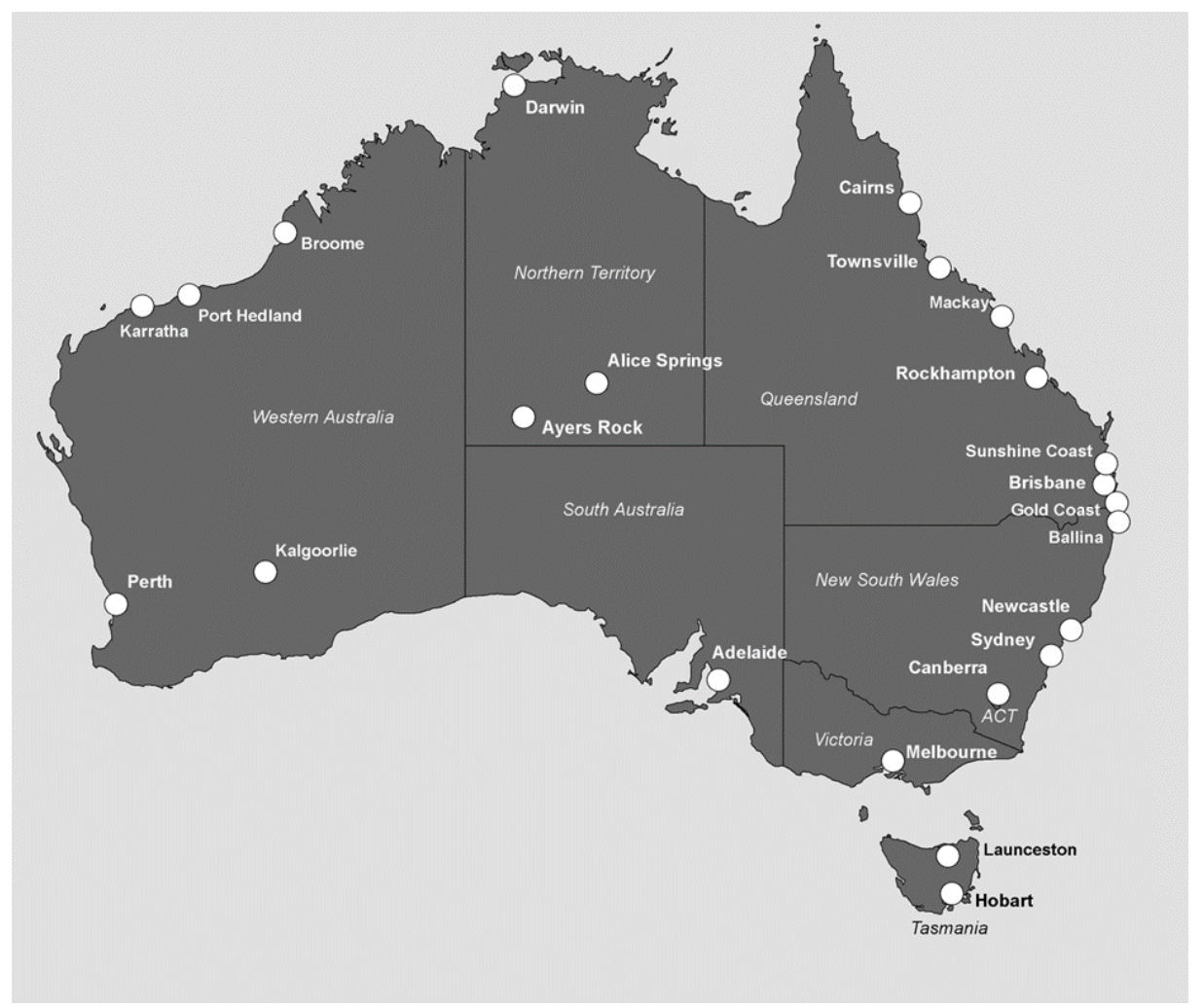




\subsection{Airline Service Networks}

The spatial structure of the Australian airline network reflects the dominance of a few cities in its urban system (O'Connor et al., 2001). As can be seen in Figure 4, there are a small number of large, and a large number of small airports. The three largest cities, Brisbane, Sydney and Melbourne along the Pacific Seaboard -- are within one or two hours flying time of one another and have many direct services. In contrast the smaller airports to the right in Figure 4 are mostly more distant, or indeed remote. Longer distance flights, on balance, should cost more, simply due to the effect on fuel and labor costs. In addition, the inter-city links from more distant locations can require a connection via a larger hub, usually adding traffic to the main links along the Pacific Seaboard. More traffic between the three major cities in this corridor justifies more daily direct connections which provide greater scope and scale for price competition. These features of the network suggest that the length of flights, and the availability of direct connections, will be influential on the air fares charged.

\subsection{Carriers and LCCS}

Though there has been considerable turmoil in the Australian aviation industry following deregulation in 1990, paradoxically growth and change within the de-regulated era has produced a duopoly not dissimilar to that of the regulated era. De Roos et al. (2010) have shown that the carriers on a route can be critical to the airfares charged, with the head-to-head competition between Qantas and Virgin having the greatest effect on price. Those effects are likely to be felt on the main inter-city routes.

It is important to consider is the role played by low cost carriers Jetstar, and originally Virgin, whose low cost role has now been taken by Tigerair. An analysis of the number of inter-city sectors flown in Australia in 2013 shows the two LCCs airlines accounted for $17 \%$ of the total (BITRE, 2013). The busiest LCC routes were between Melbourne, Sydney and Brisbane as well as to the Gold Coast, while the other large shares of LCC activity are found on some of the sectors to tourist destinations. Thus, it is clear that any understanding of Australian airfares will require recognition of the LCC presence on a route.

\subsection{Special Cases of Air Transport Demand}

There are a small number of special cases in the Australian air network. Prominent among them are small mining towns, where air services are essential for the movement of fly in-fly out labour for the management and operation of this critical and large Australian industry (McKenzie, 2010). Good examples of these are Karratha and Port Hedland. In spite of only having 14,000 inhabitants, the latter has on average three daily direct flights from Perth. The fact that fares are often paid as part 
of employment contracts removes an incentive for discounting in these markets, and it is not surprising that Karratha and Port Hedland are prominent to the right in figure 2. Though this seems an isolated effect, there is some indication that the work commuting of miners has had some overall impact on the air traffic system (Tourism Research Australia, 2013). Using data on the community profiles of the cities identified in Figure 3 (Australian Bureau of Statistics, 2011), and an analysis of the urban impact of the resources boom (Australian Bureau of Statistics 2013), we determined that a mining centre our analysis would be one where the mining industry employed $20 \%$ or more of the local workforce.

In addition, there are a large number of smaller centres with limited services. Some of these are part of Australia's tourism industry (Ayers Rock, Cairns, Hamilton Island) where price levels may be set to reflect the expected purchasing power of (international) tourists. A small number of passengers, and often a single airline, provide little scope for competition on fares, so that these places are likely to experience higher airfares. We did not explicitly account for multiple airport regions in this paper, as there is only one example where a major urban market has more than one airport (Gold Coast on the edge of Brisbane) and we have no evidence on the overlap of the markets of these two airports).

Based on this discussion, it can be expected that in the Australian domestic market, airfares will primarily reflect market forces (albeit that competition will be imperfect given the oligopoly that still exists). Available prices will reflect the overall demand for direct connections between the larger city pairs (creating pressure to lower prices), the distance between cities reflecting access to more remote places (pressure to increase prices), and the presence of LCCs (pressure to lower prices). Then on particular routes such, as those used by mining industry staff and international tourists wanting to access small remote locations, there may be some special pressures on prices. Taken at face value, many of these predictions should not come as surprise. However for a consumer planning a vacation or a travel manager planning a business trip, the key questions are: "Do these relationships hold when shopping for my low-priced domestic trip, and what is their specific effect on the fare I pay", when (for many) the lowest fare is a most important consideration.

The paper now turns to a regression analysis to confirm the effect of these several factors, indicated by the literature and Australia's particular geography. 


\section{A STATISTICAL ANALYSIS OF THE GEOGRAPHY OF AUSTRALIAN AIRFARES}

\subsection{The Data}

As noted earlier the focus of attention was a set of 24 cities (Figure 3) with airports that handled at least 1\% of Sydney's total number of domestic passengers in 2009-10 (Bureau of Infrastructure, Transport and Regional Economics, 2010). This set ranged from Sydney, with more than 21 million domestic passengers to Kalgoorlie with about 215,000 passengers (see Figure 4).

Figure 4- Passengers at 24 Australian Airports 2013

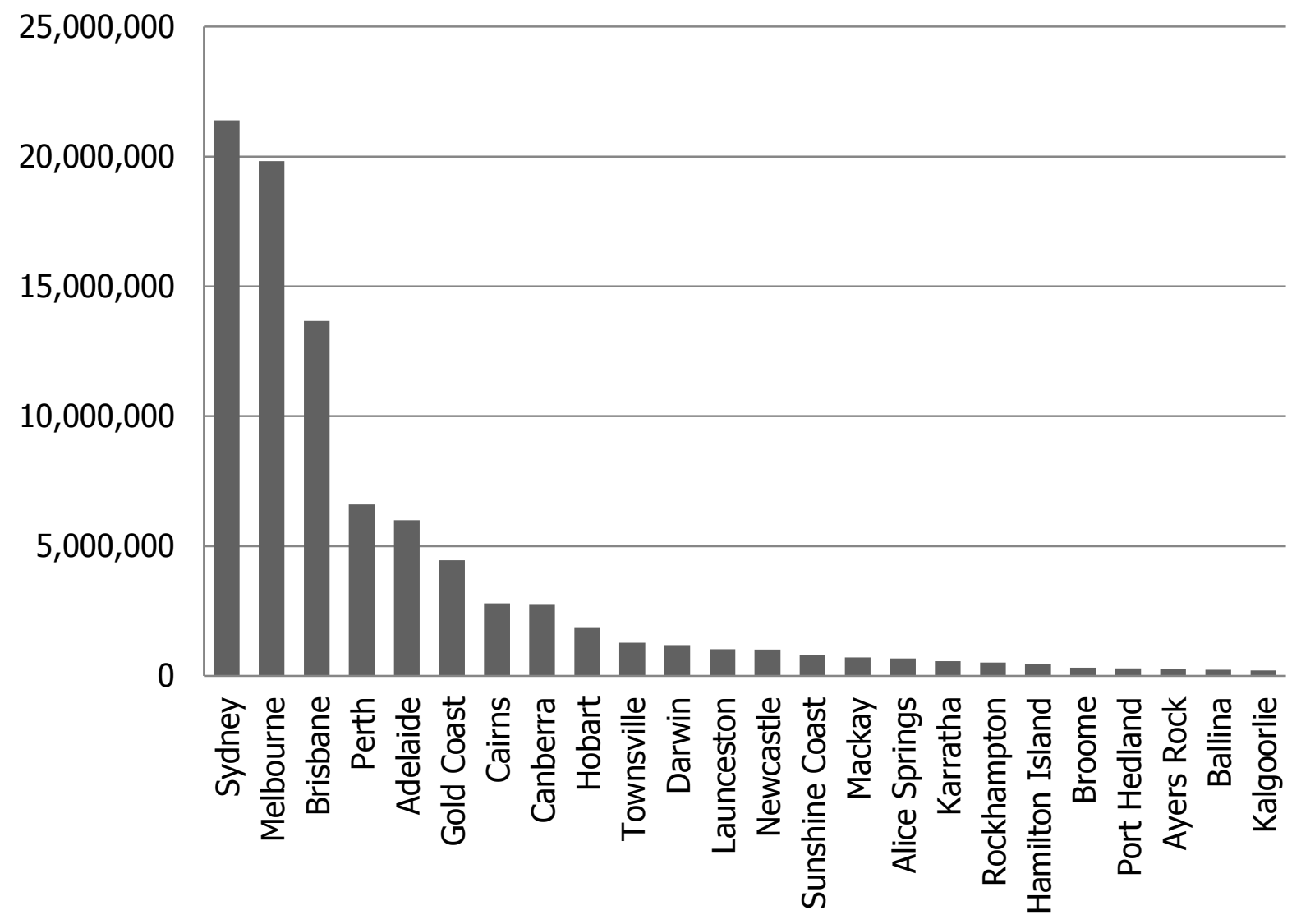

Source: BITRE Aviation Statistics.

After eliminating 10 connections where it was unlikely that air transport was the major mode of transportation (e.g. Newcastle-Sydney, Launceston-Hobart and Brisbane-Gold Coast), for the remaining connections we gathered information on the cheapest available airfare. This was obtained from Skyscanner, a passenger flight, hotel and car hire search engine that 'crawls' offers from all major carriers and can be used to find if there is a direct connection and also the cheapest deal for a desired route. We recognize that the lowest available fare may apply only to very few seats on all of the flights, and that not all consumers are searching for the lowest fare. However to accomplish 
our goal of an initial testing of the use of Skyscanner through modelling fares, we chose lowest fare as the price of interest. The airlines' willingness to advertise the availability of these low fares (even if only for a few seats) is an important expression of market competition that justifies this.

To iron out the possible effects of seasonal fluctuations, booking time, and the presence of nondaily direct connections (key influences on price as shown by De Roos et al., 2013), data were averaged for 15 December 2013, 15 March, 15 June and 15 September 2014. So for instance, the price for the Brisbane-Melbourne link is the average of the cheapest available cost on those four dates, assuming a consumer may explore different times of the year in which to take a trip. In calculating the average low fare across time it is important to note that the "typical" consumer books their ticket at a wide range of times prior to the flight. Our calculation of average lowest fares reflects the fact that such tickets are at least available more than 300 days in advance. Thus, while many flyers may not purchase their ticket nearly a year in advance, it is possible to do so.

The number of direct connections was arrived at in the same way. Given that in the Australian domestic market the cost of a one-way ticket tends to be roughly half of a two-way ticket (with the exception of booking fees etc.), we assumed A-B and B-A to be equal. This data source also enabled us to identify the number of flights available, whether direct connections were available (we found 72 city pairs) as well as whether a LCC (Jetstar or Tigerair) operated on the route. The LCC dummy variable refers to the presence of LCCs rather than competition per se. While it is possible for LCCs to have a monopoly on a route, it turned out that only Gold Coast-Cairns and Melbourne-Mackay are LCC monopolies (or were monopolies during the data gathering).

The distances of the inter-city links were based on great circle calculations of actual direct inter-city distances. The discussion earlier suggested that special attention needed to be paid to mining centres and small towns. Using the approach outlined above, we have identified Karratha, Kalgoorlie, and Port Hedland as mining centres, while 'small towns' are those with city populations less than 50,000 (Karratha, Hamilton Island, Broome, Port Hedland, Ayers Rock, Alice Springs, Kalgoorlie) Specifying the 'small city' dummy is of course contentious. We applied three thresholds (20k, $50 \mathrm{k}, 80 \mathrm{k}$ ), and there is a significant effect in all three instances. Residuals or $\mathrm{R}^{2}$ do not shift dramatically.

It is worth noting that our method of averaging ticket prices over several time periods only indirectly accounted for possible differences in service or "quality" based on the specific items included in each ticket. The "connections" parameter and more importantly the LCC parameter (see below) were proxies, since service differences in Australia (e.g., baggage allowances, etc.) are largely based upon the differences between LCCs (Tigerair, Jetstar) and full(er) service airlines (Qantas, 
Virgin Australia). However in other situations, where more complex regional, temporal, and competitive environments are found, the adjustment of fares to account for service levels via hedonic price regression may prove useful for future research (for a discussion see Papatheodorou et al., 2012). In addition, future researchers utilizing a "connections" variable may find it useful to calculate a link quality measure, as can be found in Wittman and Swelbar (2013).

\subsection{The Approach}

Based on this data, and a final sample size of 266 , we devised a simple regression model of the form:

$$
Y=a+b 1(X 1)+b 2(X 2)+b 3(X 3)+b 4(X 4)+b 5(X 5)+\text { Error }
$$

Where:

- $\mathrm{Y}$ is the average of the lowest cost fares quoted for a city to 23 others

- $\mathrm{X} 1=$ distance between each city pair

- $\mathrm{X} 2=$ the number of direct connections between each city pair (as a measure of market size)

- $\mathrm{X} 3=$ the importance of mining (a dummy variable)

- $\mathrm{X} 4=$ the existence of a small town in any city pair, measuring the effect of low demand

- X5=competition in air transport system, a dummy variable registering the presence of LCCs.

We bring the different variables together in a weighted least squares regression model to examine the relative impact of each of the variables, their overall explanatory power, and then study the exceptions through an analysis of the regression residuals. The weighed least squares approach (Ruppert and Wand, 1994) is used to maximize the efficiency of our parameter estimation given the presence of heteroskedasticity - the fact that the standard deviations of some of our variables in model estimations are not constant. In addition, we tested for the presence of multicollinearity, a statistical phenomenon in which two or more predictor variables in a multiple regression model are highly correlated (e.g. we can assume mining, small towns, and the lack of LCC presence to be correlated). In this situation the coefficient estimates of the multiple regression may be hard to interpret, and we therefore use a formal detection method - the variance inflation factor (VIF) - to comment on the credibility of the regression parameters. 


\subsection{The Results}

Our statistical results, in the form of a WLS regression equation are:

$$
Y=84.985+0.029 X 1-9.578 X 2+59.844 X 3+104.53 X 4-25.667 X 5
$$

The $\mathrm{R}^{2}$ is $87.7 \%$, with parameter estimates shown in table 1 .

The overall statistical explanation is strong, with all indicators having the expected signs and all being statistically significant. There are no problems in terms of multicollinearity or heteroskedasticity, the former of which was confirmed by VIFs and the latter tackled by using natural log of connections and applying WLS instead of OLS. It is also critical to reiterate that these findings model the cheapest fares currently available in the future - as many passengers would actually purchase if given the opportunity - rather than reverting to mean fares already paid.

Table 1 - Results of the Statistical Analysis

\begin{tabular}{|c|c|c|c|c|c|c|}
\hline \multirow[t]{2}{*}{ Model Variables } & \multicolumn{2}{|c|}{$\begin{array}{l}\text { Unstandardized } \\
\text { Coefficients }\end{array}$} & \multirow{2}{*}{$\begin{array}{l}\text { Standardized } \\
\text { Coefficients } \\
\text { Beta }\end{array}$} & \multicolumn{2}{|c|}{ Significance } & $\begin{array}{l}\text { Collinearity } \\
\text { Statistics }\end{array}$ \\
\hline & $B$ & SE & & $\mathrm{t}$ & $p$ & VIF \\
\hline (Constant) & 84.985 & 7.277 & & 11.678 & .000 & \\
\hline Distance & .029 & .003 & .335 & 10.229 & .000 & 1.206 \\
\hline \# connections & -9.578 & 1.611 & -.315 & -5.945 & .000 & 3.151 \\
\hline Mining city & 59.844 & 17.019 & .137 & 3.516 & .001 & 1.700 \\
\hline Small city & 104.530 & 11.741 & .354 & 8.903 & .000 & 1.773 \\
\hline Low-cost airlines & -25.667 & 9.112 & -.142 & -2.817 & .005 & 2.836 \\
\hline
\end{tabular}

These results confirm that the prices charged for airfares at Australian cities reflect the interactions between the spatial distribution of the market and the operational response of the airlines. The distribution of the market is captured by three measures. The first, distance between cities, is the statistically strongest effect (see Table 1) and shorter flights are cheaper, which is expected. In Australia however most short distance flights are along a corridor that includes the three largest cities, the nation's largest tourist destination and the nation's capital. Hence the benefits of low fares seem to be greater in just a small part of the country. That observation is reinforced by the small city variable, the second market measure in our analysis. Several different size measures were used for this variable, but the overall results were the same, confirming its consequence. The results show the smaller the city the higher the airfare. Smaller cities usually have fewer flights - so 
the competitive market pressures are lower. The simple measure for the mining industry was also statistically significant, showing that its unusual large and regular business passenger demand in remote locations flows over into the prices charged.

The effect of the airline industry's operations were measured statistically in the model by the number of direct flights and presence or absence of a LCC. In this analysis the number of direct flights is the second strongest influence on fares. The more direct flights available, the lower are the fares between cities. Large, closely spaced markets are more likely to be served by direct flights. On these routes Qantas and Virgin can use yield management strategies to offer discounts at certain times of the day, or on some days of the week. That influence on fares is strengthened by the presence of Jetstar and Tigerair for whom direct flights (with quick turnarounds) are a key part of their business strategy. These two broad effects are obviously interdependent as closely spaced large markets are more likely to have direct connections by both full service and LCC airlines and as a result maintain strong downward pressure on fares. Hence the geography of Australia's urban settlement itself is a key influence on the geography of its airfares.

Our modelling approach produced accurate estimates of the actual value of fares for the larger city pairs. However, it was less accurate for some other city pairs. The ten largest residuals (or error terms), both for under-predictions and over-predictions, are shown in Table 2 and close study of them provides some more research insight. The ten city pairs in the top half of the table are routes where the statistical model underestimated the actual fares charged on the route. It is apparent that there are special additional factors at work in remote places with special tourist attractions. Ayers Rock, Alice Springs and Broome figure in nine of the city pairs in the top half of the table. The special factors that shape the fares charged to these locations are probably associated with remoteness and the sheer difficulty of access, especially for tourists with limited flexibility in their travel arrangements (e.g., fixed trip times). In addition, on some of these routes, on some days, one airline can have a monopoly position.

On the routes listed in the bottom half of the Table, airfares are lower than the statistical approach would suggest, although the size of the errors are much less than those recorded at the cities at the top of the table. Routes from a few places (mainly from smaller and distant ties) to Hamilton Island are the main example here, which may be because special promotional fares are used to attract consumer attention on these routes. 
Table 2 - Residual Values from Regression Analysis

Airfares Under-Estimated

City Pairs

Karratha

Ayers Rock

Sunshine Coast

Broome

Port Hedland

Alice Springs

Sunshine Coast

Broome

Mackay

Mackay
Ayers Rock

Kalgoorlie

Rockhampton

Ayers Rock

Ayers Rock

Broome

Broome

Port Hedland

Ayers Rock

Broome

\section{Standardized Residual}

4.61

3.83

3.55

3.54

3.25

2.67

2.29

2.26

2.19

2.15

Airfares Over-Estimated

City Pairs

Adelaide

Newcastle

Canberra

Launceston

Perth

Adelaide

Sydney

Canberra

Brisbane

Brisbane
Standardized Residual

Ballina $\quad-1.70$

Hamilton Island $\quad-1.68$

Ballina

$-1.57$

$-1.55$

$-1.50$

$-1.47$

$-1.46$

$-1.44$

$-1.37$

The fact that the major positive and negative error terms relate to just two broad classes of locations underscores the overall effectiveness of the modelling approach across the majority of cities and especially in the major eastern seaboard corridor. It should be particularly noted that the standardized residuals of the over-estimated airfares are all really quite small. Further calibration of some variables may prove valuable in future applications of the method, particularly where the model underestimated airfares. 


\section{DISCUSSION AND CONCLUSION}

As both leisure and business consumers sit in front of their keyboard shopping for flights, the pricing of air transportation may seem to be a "black box." A substantial contribution of the paper was to use a new database which searches for low fares and mimics the process of consumer shopping before purchase. In Australia, perhaps because the route system is rather simple (say in comparison to China, The United States, or the EU) we found that this insight on pricing system was somewhat transparent and easy to relate to the pattern of cities and air services.

In this paper we have collected and analysed low fare data available to all consumers through Skyscanner. Although lowest offered fare is but one slice of ticket sales, it is an important one both for savvy consumers and for airlines promoting services. The confirmatory statistical analysis presented here was successful in modelling these fares in the Australian contest, demonstrating that both the analytical technique and data source have merit. We showed that almost $90 \%$ of the variance in lowest available airfares across the busiest 24 airports in cities in Australia is associated with just five variables, which is perhaps all the more impressive given that some of our measures in this initial trial with the data set are rather coarse. Nevertheless, these variables measure the patterns of settlement and the operations of the airlines. In essence the geography of airfares reflects Australia's urban geography with lowest fares in a narrow coastal corridor, medium fares in smaller centres across the rest of the nation and very high fares in remote tourist locations. Data shows that the difference from the cheapest to the most expensive routes is a multiple of 3.5 times.

This outcome is a major contrast to the controlled fares of the regulated duopoly where crosssubsidies from busy routes kept fares lower on less-busy routes, as outlined by Weller (2007). Deregulation has meant a steady shift away from that circumstance. As Goetz and Vowles (2009) observed, the outcomes of deregulation can be "good, bad or ugly". In Australia, it seems the "good" is found on flights between Melbourne and Sydney, while the "ugly" is seen in the isolated inland. In effect, the market- focussed deregulation of the airline industry, which underscores the economies of airline operation in densely-settled short corridors, favours the big and the clustered against the small and the dispersed. That such a result has been achieved in a simple urban system may provide a timely warning for policy makers in other nations. Our results show falls in average airfares can be a misleading view of the outcomes of deregulation. The long term management of a deregulated market requires not only monitoring of average fares but also requires careful and regular monitoring of air fares on a sample of routes, which should be linked to a capacity for action where actual air fares can be shown to be are well above estimated operating costs. 
An extension of that thinking will require two areas for further research on the impact of deregulation. One involves closer attention to the circumstances surrounding air services to small towns and remote locations where above average fares are likely. Although airline operations to these places are fundamental to the accessibility of resident communities, there seems to be limited research attention paid to the type, frequency and competitive arrangements of services on these routes. At the very small and isolated end of the scale some of the services will be subject to subsidy; this applies in the U.S. (Grubesic and Matisziw (2011) and Australia (Australian Government, 2013). Can a fare analysis like that carried out here identify routes that call for further action?

The second area deserving closer attention is the operation of low cost carriers, again dealt with in simple terms here. The aggregate data assembly undertaken here suggests that LCCs are moving beyond the busy inter-city and major tourist markets to serve a wider array of destinations. To what extent is this shift by full service carriers to gain cost advantages and move into different union labour arrangements? What has been the change over time in the routes served by LCCs? If that shows a shift into the smaller city end of the market what has been the effect on fares? These two broad set of questions will require additional data for which Skyscanner may be useful. 


\section{REFERENCES}

- Australian Bureau of Statistics (2011) Census 2011: Community Profiles. Available at: http://www.abs.gov.au/websitedbs/censushome.nsf/home/communityprofiles. / /accessed March 15 2015).

- Australian Bureau of Statistics (2013) Australian Social Trends: Towns of the Mining Boom . Available at: http://www.abs.gov.au/AUSSTATS/abs@.nsf/ Lookup/4102.0Main+Features10April+2013\#p3. / (Accessed March 15 2015).

- Alderighi, M., Cento, A., Nijkamp, P., \& Rietveld, P. (2004) The entry of low-cost airlines: price competition in the European airline market (No. 04-074/3). TinBergen Institute Discussion Available from http://papers.tinbergen.nl/04074.pdfPaper / (accessed February 18 2014)

- Australian Government (2009) Flight Path to the Future. National Aviation Policy White paper. Canberra. Australian Government.

- Australian Government (2013) Remote Air Services Subsidy Scheme. Department of Infrastructure and Regional Development. Canberra. Available from: (http://www.infrastructure.gov.au/aviation/regional/rass.aspx / (accessed April 23 2014).

- Bowen, J. (2002). Network Change, Deregulation, and Access in the Global Airline Industry. Economic Geography, 78425-439.

- Brueckner, J. K., Lee, D., \& Singer, E. S. (2013). Airline Competition and Domestic US Airfares: A Comprehensive Reappraisal. Economics of Transportation, 2, 1-17.

- Derudder, B. \& Witlox, F. (2009) The Impact of Progressive Liberalization on the Spatiality of Airline Networks: A Measurement Framework Based on the Assessment of Hierarchical Differentiation. Journal of Transport Geography 17, 276-284.

- Forsyth, P. (1991). The Regulation and Deregulation of Australia's Domestic Airline Industry. Airline Deregulation: International Experiences. David Fulton Publishers, London, 48-84.

- Forsyth, P. (2003). Low-cost Carriers in Australia: Experiences and Impacts. Journal of Air Transport Management, 9, 277-284.

- Fuellhart, K. and O'Connor, K. (2012) Air Services at Australian Cities: Change and Inertia 20052010, Geographical Research, 51, 37-48.

- Fuellhart, K., O'Connor, K., and Woltemade, C. (2013) Route-level Passenger Variation Within Three Multi-airport Regions in the U.S.A., Journal of Transport Geography, 31 171-180.

- Gillen, D., \& Morrison, W. G. (2005). Regulation, Competition and Network Evolution in Aviation. Journal of Air Transport Management, 11, 161-174.

- Goetz, A. R. (2002). Deregulation, Competition, and Antitrust Implications in the US Airline Industry. Journal of Transport Geography, 10, 1-19. 
- Goetz, A. R., \& Graham, B. (2004). Air Transport Globalization, Liberalization and Sustainability: Post-2001 Policy Dynamics in the United States and Europe. Journal of Transport Geography, $12,265-276$.

- Goetz, A. R., \& Vowles, T. M. (2009). The Good, the Bad, and the Ugly: 30 Years of US Airline Deregulation. Journal of Transport Geography, 17, 251-263.

- Grubesic, T. H., \& Matisziw, T. C. (2011). A spatial analysis of air transport access and the essential air service program in the United States. Journal of Transport Geography, 19(1), 93105.

- Hazledine, T. (2010) "Pricing, Competition and Policy in Australasian Air Travel Markets." Journal of Transport Economics and Policy 44, 37-58

- Kain, J. and Webb, R. (2003) Turbulent Times: Australian Airline Industry Issues. Australian Parliamentary Library Research Paper 10. Canberra. Parliament of Australia. Available at:http://www.aph.gov.au/About Parliament/Parliamentary Departments/Parliamentary Library/pubs/rp/rp0203/03RP10. /(Accessed April 20 2014).

- Lee, D., \& Luengo-Prado, M. J. (2005). The Impact of Passenger Mix on Reported" Hub Premiums" in the US Airline Industry. Southern Economic Journal, 72, 372-394.

- McKenzie, F. H. (2010). Fly-in fly-out: The challenges of Transient Populations in Rural Landscapes. In Luck, G.W., Race, D. and , Black, R.(eds.) Demographic Change in Australia's Rural Landscapes Implications for Society and the Environment. Landscape Series, Vol. 12 . Dordrecht. Springer and CSIRO Australia, PP. 353-374.

- Mentzer, M. S. (2000). The Impact of Discount Airlines on Domestic Fares in Canada. Transportation Journal, 39, 35-42.

- Neal, Z. (2014). AIRNET: A Program for Generating Intercity Networks. Urban Studies, 51, 136 152.

- O'Connor, K., R. Stimson, and M. Daly (2001) Australia's Changing Economic Geography: A Society Dividing. Oxford University Press. Melbourne.

- O'Kelly, M. E. (1998). A Geographer's Analysis of Hub-and-Spoke Networks. Journal of transport Geography, 6, 171-186.

- Papatheodorou, A., Lei, Z. and Apostolakis, A. (2012) Hedonic Price Analysis. In Dwyer, L., Gill, A. and Seetaram, N. (eds) Handbook of Research Methods in Tourism: Quantitative and Qualitative Approaches, Cheltenham: Edward Elgar Publishing, 170-182.

- Pels, E., \& Rietveld, P. (2004). Airline Pricing Behaviour in the London-Paris Market. Journal of Air Transport Management, 10, 277-281. 
- Quiggin, J. (1997). Evaluating Airline Deregulation in Australia. Australian Economic Review, 30, 45-56.

- Reynolds-Feighan, A. (2001). Traffic Distribution in Low-cost and Full-service Carrier Networks in the US Air Transportation Market. Journal of Air Transport Management, 7, 265-275.

- De Roos, N., Mills, G., \& Whelan, S. (2010). Pricing Dynamics in the Australian Airline Market. Economic Record, 86, 545-562.

- Ruppert, D., \& Wand, M. P. (1994). Multivariate Locally Weighted Least Squares Regression. The Annals of Statistics, 22, 1346-1370.

- Tanjea, N. (2004). Simpli-Flying: Optimising the Airline Business Model. Farnham: Ashgate.

- Tourism Research Australia (2013) The Economic Impact of the Current Mining Boom on the Australian Tourism Industry. Canberra. Available from: www.tra.gov.au/documents/ EconomicIndustry/Economic_Impact_of_the_Current_Mining_Boom_on_the_Australian_Tourism _Industry_FINAL.pdf. / (accessed February 22 2014).

- US Department of Transportation (2005) Data Review : Employment in the Airline Industry. Journal of Transportation and Statistics Volume 8 Number 1( no page numbers) Available at: http://www.rita.dot.gov/bts/sites/rita.dot.gov.bts/files/

publications/journal of transportation and statistics/volume 08 number $01 / \mathrm{html} / \mathrm{data}$ review/i ndex.html. / (Accessed February 23 2014).

- Weller, S. (2007). Strategy and the Contested Politics of Scale: Air Transportation in Australia. Economic Geography, 83, 137-158.

- Weller, S. A. (2009). Shifting Spatialities of Power: The Case of Australasian aviation. Geoforum, 40,790-799.

- Wittman, M., and Swelbar, W. (2013). Modeling Changes in Connectivity at U.S. Airports: A Small Community Approach. MIT International Center for Air Transportation. Report Nol.: 201305. Available at: http://dspace.mit.edu/bitstream/handle/1721.1/ 79091/ICAT-2013-05.pdf?sequence=1. / (Accessed March 2015).

- Yamauchi, H. (2000). Toward a More Liberal Sky in Japan: An Evaluation of Policy Change. In Deregulation and Interdependence in the Asia-Pacific Region, NBER-EASE Volume 8 (pp. 195225). University of Chicago Press.

- Zhang, A., Hanaoka, S., Inamura, H. and Ishikura, T. 2008. Low-cost Carriers in Asia: Deregulation, Regional Liberalization and Secondary Airports, Research in Transportation Economics $24,36-50$.

- Zhang, S., Derudder, B. \& Witlox, F. (2013) The Impact of Hub Hierarchy and Market Competition on Airfare Pricing in the US Hub-to-Hub markets. Journal of Air Transport Management, 32, 65-70. 
- Zook, M.A. and Brunn, S.D. (2005) Hierarchies, Regions and Legacies: European Cities and Global Commercial Passenger Air Travel, Journal of Contemporary European Studies, 13, 203220.

- Zook, M.A and SD Brunn, S.D (2006) From Podes to Antipodes: Positionalities and Global Airline Geographies, 96, Annals of the Association of American Geographers. 